

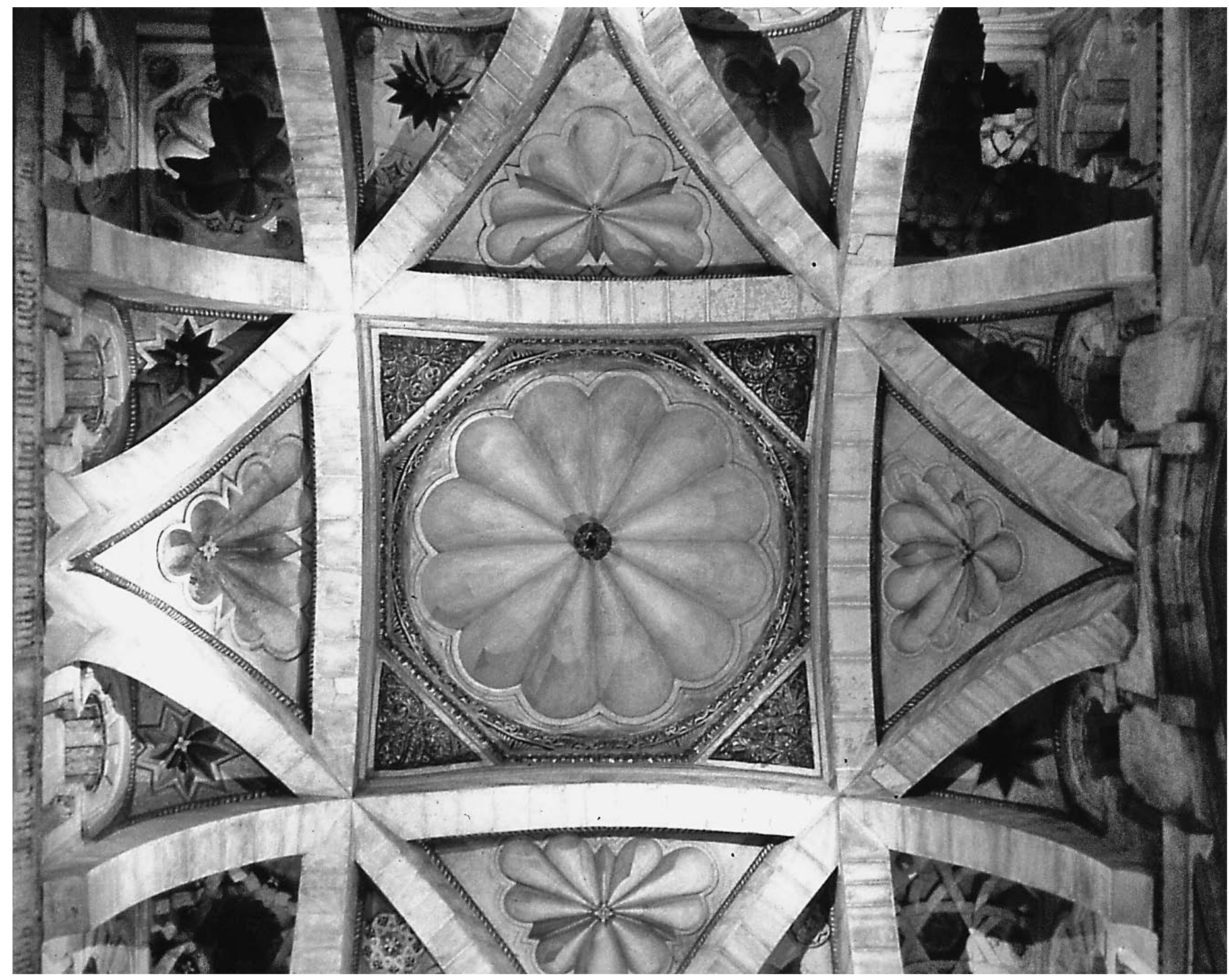

Fig. 1 Córdoba, Great Mosque, dome over third extension entrance (962-5) [Author's photo (2007)] 


\title{
SenAd Nanić
}

University of Zagreb, Faculty of Architecture, Fra Andrije KaČića Miošıća 26, 10000 Zagreb, Croatia

(D) ORCID.ORG/0000-0002-1170-7269

senad.nanic@zg.t-com.hr

Preliminary Communication

https://doi.org/10.31522/p.29.2(62).3

UDC 514 726:28-523.42 (460.351.2)

Technical Sciences / Architecture and Urban Planning

2.01.03. - Architectural Structures, Building Physics, Materials and Building Technology

Article Received / AcCepted: 13. 10. 2021. / 17. 12. 2021.

\section{An Alternative Approach to Geometric Harmonization of the GReat Mosque in Córdoba}

\author{
ALGEBRAIC EXPRESSION \\ GEOMETRIC HARMONIZATION \\ GEOMETRIC SEQUENCE \\ GOLDEN SECTION \\ Great Mosque, Córdoba, Spain \\ ISLAMIC ARCHITECTURE
}

This research constitutes an alternative to proportional composition studies of the original Great Mosque and its four extensions in Córdoba, based on diagonals of a square and rectangles in ratio $1: \sqrt{ } 2$ and 1: $\sqrt{3}$ (Fernández-Puertas, 2000, 2008). The method for this alternative research consists of graphic analyses by iteration of hypothetical products of the golden section in AutoCAD 2D software conducted on architectural drawings of the original Great Mosque and its four extensions, in reconstruction, according to measurements from the relevant literature. The alternative method insists on geometric harmonization derived from only one starting length in all drawings of same scale. It resulted in the production of a single harmonization pattern based on the golden section, with an additional sequence of $a \sqrt{ } 2 / \Phi^{n}$, successively developed for the original monument and its four extensions. It also includes otherwise excluded basic composition elements (minarets) and reveals otherwise hidden proportional qualities. The alternative approach enabled a deduction of algebraic expressions having only one variable for all drawings of the same scale. Their arithmetic values and deviations from real dimensions are calculated. Geometric harmonization by golden section with another starting length is applied to the drawing of the elevation at a different scale. 


\section{INTRODUCTION}

xplanation of subject matter ${ }^{1}-$ The subject matter is conceived as congruent to the dominant historical and essentialist discourse in research on Islamic architecture. Geometrically elaborate Islamic architecture inevitably spurs a quest for geometric principles as the basis of recognizable unity actualized from composition to structure and decoration, not only on a particular monument, but within a particular style and even its entirety. Architectural drawings of monuments, once subjected to graphic analyses, based on the iteration of hypothesized geometric principles, create the possibility for objective interpretation and contextualization of the architectural value of particular work.

Architectural design is not governed by proportions of specific parts. Rather, it tends to a comprehensive and consistent geometric system that harmoniously governs the dimensions of all essential building elements. The more applicable the system is to design requirements, i.e., the requirements of dimensioning a structure's elements, the more harmonious the result. Hence the term geometric harmonization.

The research is particularly focused on proportional compositions based on the golden section (dividing a line at a point so that the ratio of the line and the larger segment, denoted as $\Phi$, equals the ratio of the larger and smaller segments, known in classic Greek and Islamic tradition as the division of a line into mean and extreme ratio). The research serves as an alternative to the proportional compositional study of the Great Mosque in Córdoba, based on the diagonals of a square and rectangles in $1: \sqrt{ } 2$ and $1: \sqrt{3}$ ratio (Fernández-Puertas, 2000, 2008). It is the only proportional study of the Great Mosque in Córdoba available and one of the best and most influential studies of its kind.

Significance of the Great Mosque in Córdoba - Besides its exceptional architectural value, the Great Mosque of Córdoba is noteworthy as a monumental vestige of almost three hundred years of flourishing Muslim rule in Iberia by the Umayyad dynasty, i.e., the Emirate/Caliphate of Córdoba (756-1031). Despite its extensions, the Great Mosque in Córdoba is one of the few monuments of the first two centuries of Islamic architecture with significant parts of the original structure. Moreover, the latter, specifically the preserved original two-story arcades, are monumental in character and innovative in structure.

All four extensions of the Great Mosque, excluding the Gothic cathedral's insertion, respect the basic spatial and structural concept. This has been achieved by repetition of the spans, height and structure of the original two-story arcades in the extended covered parts of the Mosque (Fig. 2ii; 2iv; 2v). The layout position of the original minaret, alongside the outer wall of the Mosque's yard, is followed by the second extension's new minaret position and preserved by the later extension of the yard (Fig. 2i; 2iii; 2v).

Research methodology and hypothesis - The research method consists primarily of deductive graphic analysis via iteration of hypothetic geometric principles, applied to architectural drawings of an extant building. In the approximate analyses, not presented here, the templates are digitized and analyzed in AutoCAD 2D software. Architectural drawings of the Great Mosque in Córdoba, published with proportional analyses based on diagonals of a square and rectangles in $1: \sqrt{ } 2$ and 1:V 3 ratio (Fernández-Puertas, 2000, 2008), are hereby subjected to alternative hypothetic geometric analyses based on the golden section. The research hypothesis is that the alternative geometric harmonization of the original Great Mosque in Córdoba and its four extensions is a product of the golden section.

The subject of the detailed analyses is deduced from those approximate analyses that have their architectural drawing dimensions

1 This research was conducted as a component of work on the undefended doctoral dissertation entitled Geometric Harmonization in Islamic Architecture, supervised by Prof. Zlatko Karać, Ph.D., and Assist. Prof. Marija Simic Horvath, Ph.D., at the University of Zagreb, Faculty of Architecture. 


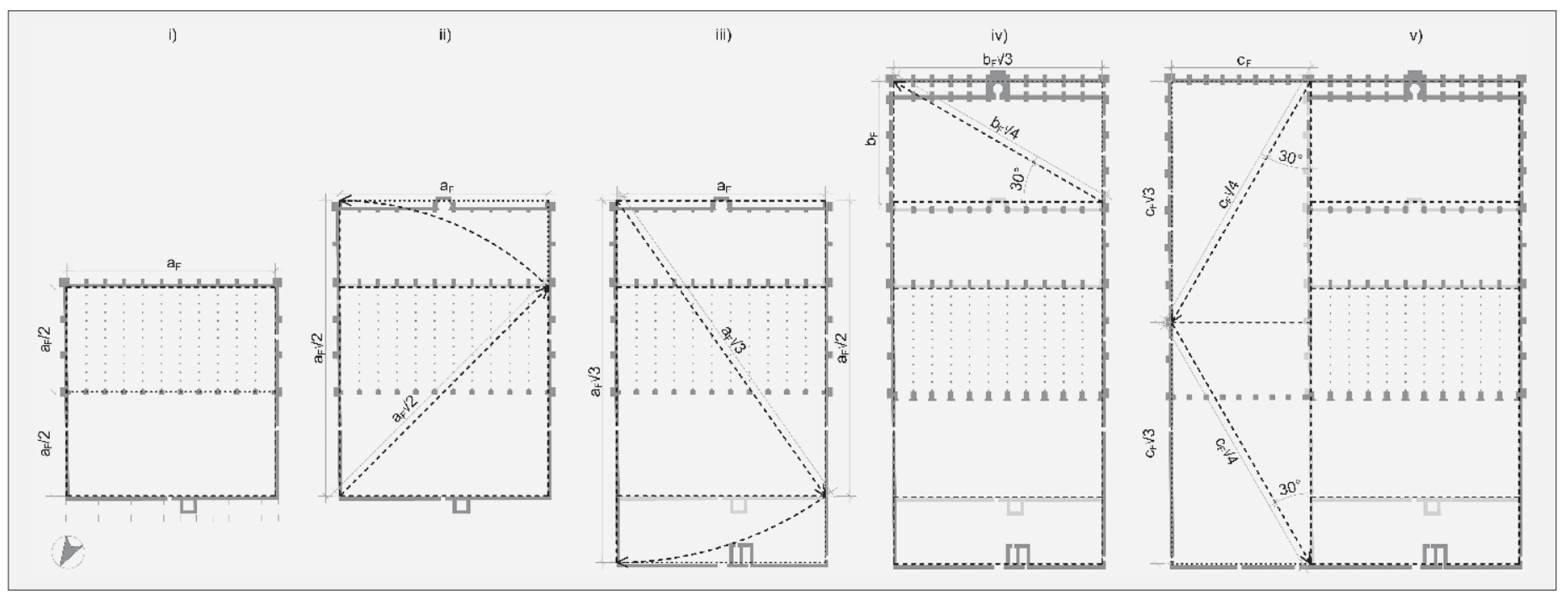

published in the literature, in a manner that enabled graphic reconstruction of layouts and one elevation in AutoCAD 2D software, with or without negligible deviations. Unlike the proportional analyses by FernándezPuertas $(2000,2008)$, these analyses insist on the geometric harmonization method based on only one starting length in all drawings of the same scale, and another applied to a drawing of the elevation at a different scale. This methodological rigor resulted in the deduction of algebraic expressions with only one variable for all drawings of the same scale for the entire monument.

\section{REVIEW OF THE LITERATURE}

The only published scientific book dedicated exclusively to the geometric harmonization in Islamic architecture, albeit with regional limitations, is Bulatov (1988). Its pioneering presentation of the aesthetic and mathematical sources of the Islamic theory of architecture gives it additional value. Based on the detailed analyses of 47 Central Asian monuments dating from the $9^{\text {th }}$ century onward, Bulatov demonstrated "a systematic evolution of architectural form from elementary, based on squares and equilateral triangles, to more complex, based on half-squares and the division of lines into mean and extreme ratio [i.e., golden section]" (Bulatov, 1988: 301). Geometric harmonizations based on the golden section are demonstrated in detail on single monuments by Boussora and Mazouz (2004) and Azizova (2015). Initial geometric harmonizations of two monuments based on the golden section are done by Hejazi (2005).

Geometric harmonization based on diagonals of a square and rectangles in $1: V_{2}$ and $1: V_{3}$ ratio has been demonstrated in detail in the
Great Mosque of Córdoba by FernándezPuertas $(2000,2008)$. Fundamental usage of equilateral triangles in geometric harmonization has been demonstrated in detail on two monuments in Maghrib by Ewert (1986), and without detailed analyses by Arnold (2017). Geometric harmonizations based on the diagonal of the square are demonstrated in detail on single monuments by Ewert (1986) and Tabbaa (2008), and without detailed analyses by Creswell (n.d.). Proportions based on modular nets are demonstrated on single monuments with no detailed analyses by Klingelhofer (1988), Tabbaa (1988), Begley and Desai (1989), Blasi (1997), and in detail by Balasubramaniam (2009).

A series of initial geometric harmonizations based on arithmetic ratios without detailed analyses were done by Tuncer (1986). A review of studies of integer and irrational ratios in the proportions of Ottoman monuments is provided by Sağdiç (2015). Six initial geometric harmonizations, based on grid-patterns originating from the division of a circle without detailed analyses, are done by El-Said and Parman (1976). Initial geometric harmonizations based on square division and a combination of different symmetries on single monuments with no detailed analyses are done by Critchlow (2011), Mir (1996), Pour Ahmadi (2012) and Burckhardt (2009). A geometric harmonization of the northern dome chamber of the Juma Mosque in Esfahan, based on products of a rectangular triangle that has its longest side equal to the sum of its shortest side and its height, is done in detail by Özdural (2015).

The variety of geometric methods for the construction of $2 \mathrm{D}$ patterns is best presented by Bulatov (1988), Crtichlow (2011), El-Said and Parman (1976), Pūrnādarī (2000/1) and Lor-
FIG. 2

BUILDING, CONSTRUCTION DATES: CóRdobA, GREAT Mosoue, 785, 848, 951/2-8, 962, 988

CONSTRUCTION PHASES: ORIGINAL FORM (I) AND FOUR EXTENSIONS (II-V)

CONTENT AND DRAWINGS: PROPORTION ANALYSES OF LAYOUTS, ACCORDING TO FERNÁNDEZ-PUERTAS, 2000: 220 (2), 227 (5); 232 (7); 236 (10); 242 (14) 


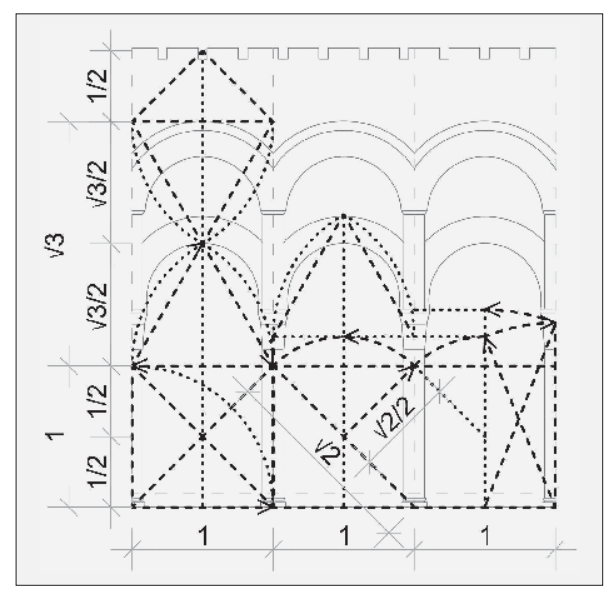

FIG. 3

BUILDING, CONSTRUCTION DATE: CÓRDOBA, GREAT MOSQUE, 785

CONSTRUCTION PHASE: ORIGINAL FORM

CONTENT AND DRAWING: PROPORTION ANALYSES OF ARCADE NORTHEASTERN ELEVATION, ACCORDING TO FERnÁNDEZ-PuERTAS, 2008: 342 (11), $343(12,13)$, 344 (14) zādeh (1995/6). El-Said (1993) supplemented his method primarily by producing approximate integers for irrational values of geometric $2 \mathrm{D}$ patterns without any reference to architectural proportions. ${ }^{2} \mathrm{~A}$ review of basic methods is given by Dabbour (2012), without any reference to architectural proportions. Pentagonal symmetry and the golden section based $2 \mathrm{D}$ patterns in particular are studied in articles by Lu and Steinhardt (2007), Makovicky (1992), Fleurent (1992), Chorbachi and Loeb (1992) and Sarhangi (2012). Multilayered patterns are studied by Bier (2012). The pattern based on a rectangular triangle that has its longest side equal to the sum of its shortest side and its height is studied by Özdural (1995, 2000, 2015).

The general literature on proportioning in the arts and architecture, in particular Padovan (1999) and March (1998), demonstrate a great variety of methods, excluding those in Islamic arts and architecture. Comprehensive and insightful research into the application of the golden section in the arts and architecture, excluding Islamic, is done by Pejakovic (2000). The general literature on Islamic architecture hardly ever mentions geometric harmonization, but does offer an abundance of recorded and contextualized morphological concepts and architectural drawings suitable for approximate analyses, in particular Hillenbrand (1994), Ettinghausen, Grabar and Jenkins-Madina (2001), Creswell (1932, 1940), Michell (ed., 1991), Frishman and Khan (ed., 1994), Bentley Śevčenko (ed., 1988) and the journals Ars Orientalis, Muqarnas and Nexus Network Journal. The most comprehensive and coherent critical historical research into social and theoretical contexts can be found in Necipoğlu (1995). The best theoretical work using the essentialist approach is Burckhardt (2009).

The variety of geometric methods for the construction of patterns in Islamic arts is well studied in literature. However, only occassionally is it coupled with research into the geometry applied in Islamic architectural compositions. Moreover, only a few of such studies are detailed enough to corroborate their initial hypothetical geometric compositions.

\section{PROPORTION ANALYSES OF THE GREAT MOSQUE IN CÓRDOBA BY FERNÁNDEZ-PUERTAS}

Fernández-Puertas demonstrated proportioning of the fourfold extended layout of the Great Mosque in Córdoba (Fig. 2) "based on the side of a square $(=1)$, its diagonal $(=\sqrt{2})$, and the successive proportional rectangles that are formed with the diagonal of the previous rectangle... $V_{2}$ rectangle and $\sqrt{3}_{3}$ rectangle" (Fernández-Puertas, 2000: 217). ${ }^{3}$ The original mosque dates to 785 (FernándezPuertas, 2000: 223). It was expanded the first time in 833-48 (Yetkin, 1965: 35), the second time in 951/2-8 (Fernández-Puertas, 2000: 231), the third time in 962-5 (Fernández-Puertas, 2000: 235), which included the innovative segmented domes and arches, and the fourth time in 988 (Fernández-Puertas, 2000: 243). ${ }^{4}$ Fernández-Puertas demonstrates the enlargement of the mosque's original square layout (Fig. 2i) by the first extension (Fig. 2ii) by taking the side of the square as "length unit (=1)" and rotation of "the square diagonal $(=\sqrt{2})$ ", thus “obtaining the rectangular $V_{2}$ layout” (Fernández-Puertas, 2000: 226). He demonstrates the second extension (Fig. 2iii) by "rotating the diagonal of the rectangle $\sqrt{2}$, with a value of $\sqrt{3}_{3}$ on the longitudinal sides, so a new extension is constructed with rectangular v 3 layout" (Fernández-Puertas, 2000: 231). For the third extension (Fig. 2iv), he took "the mosque's width (=1) as the longitudinal length of a rectangle $v_{3}$ on a smaller scale, with a $30^{\circ}$ angle applied" (Fernández-Puertas, 2000: 235). If we express it with unit length $(=1)$, this means that he demonstrated the layout of the third extension as equal to a rectangle with sides 1 and $1 / v_{3}$, thus obtaining $\sqrt{ } 3+1 / \sqrt{ }_{3}$ for the total length of the mosque. He demonstrated the fourth extension (Fig. $2 \mathrm{v})$ as "adding two rectangles $v_{3}$ " (Fernández-Puertas, 2000: 243). If expressed with unit length $(=1)$, he in fact obtained the extension by a rectangle with a longer $\sqrt{3}_{3}+1 / \sqrt{3}_{3}$ and shorter side $\left(\sqrt{3}_{3}+1 / \sqrt{ }_{3}\right) /\left(2 \sqrt{ }_{3}\right)$.

The lines as part of the architectural drawings used by Fernández-Puertas in his analyses provided sufficient dimensions to reconstruct the drawings in AutoCAD 2D software (Fig. 2). However, he neither declared the unit's dimensions, i.e., the starting length, designated here as $a_{F}$, nor is it deducible from his drawings, except approximately since the square side lengths, both net and gross, differ.

Fernández-Puertas defines the axle span of the longitudinal central nave of the original mosque by rotation of the shorter sides of the mosque's covered half, that is, half of the starting square, centered in the outer corners producing, in fact, two equilateral triangles constructed on half of the initial length,

2 The sole copy of the 2001 edition is otherwise available in the National Library of Denmark / Royal Library in Copenhagen, but has been out on loan since 2019.

3 The finding was first published with no drawings by Fernández-Puertas, 1994: 101-104, 110.

4 Ettinghausen, Grabar and Jenkins-Madina exclude the second extension from, as they see them, the three major extensions as they only associate it with the construction of a new minaret in 951/2 (Ettinghausen, Grabar and Jenkins-Madina, 2001: 84-85). Fernández-Puertas sees it as a major extension, since it included extension of the layout with a new outer wall (Fernández-Puertas, 2000: 231). 
while he defines the remaining five naves both to the left and right of the central nave by division of the line into five equal segments [Fernández-Puertas, 2008: 337, 339 (5), $340(6)]$.

By applying the sum of the heights of the square and equilateral triangle constructed on the axle arch span of the original arcade $(=1)$, Fernández-Puertas defines the net height in the lower arch vertex (Fig. 3), designated here by the algebraic expression $\left(1+v_{3} / 2\right)$, while he defines the gross height of the upper arch vertex by the addition of the equilateral triangle's equal height $\left(1+v_{3}\right)$ and the net height of the room by three halves of the starting length and two equilateral triangle heights $\left(3 / 2+V_{3}\right)$ [Fernández-Puertas, 2008: 345, 344 (14)]. By rotating half of the starting square diagonal (Fig. 3), he defines a height $(1 / 2+\sqrt{2} / 2)$, which when rotated defines the height of a column with capital, the latter being rotated there upon to define the height of the arch spring [Fernández-Puertas, 2008: 344, 343 (12)]. He defines the gross height in the lower arch vertex by the height of the equilateral triangle (Fig. 3) based on height $1 / 2+\sqrt{2} / 2$ [FernándezPuertas, 2008: 344, 343 (13)].

\section{ANALYSES}

Methodology - Five analyses (A:1 - A:5) have been conducted, corresponding to the original form and the four extensions on six architectural drawings (Figs. 4-9). Each analysis is introduced by providing basic information on the building and construction phase with the source of the graphic reconstruction of the architectural drawings. Geometrical analyses begin by defining only one starting length for all layouts and the other for the arcade section (Fig. 4) as a result of numerous iterations not presented here. Geometric analyses are marked by dashed and dotted black lines drawn on grayscale architectural drawings with light gray dimension lines and parts of the building demolished by a later reconstruction phase. The geometric definition of architectural elements is then translated into algebraic expression. The geometric harmonization of an extension phase is additionally marked in a drawing by respective algebraic expressions on dimension lines. The specific and innovative values of applied harmonization in a respective case, accompanied by comparison with the harmonization demonstrated by Fernández-Puertas, are stated.

In cases where more than one graphic reconstruction was possible, the chosen reconstruction based on the iteration process was the one that last deviated from the dimensions specified in the architectural drawings by Fernández-Puertas. In cases where differ-

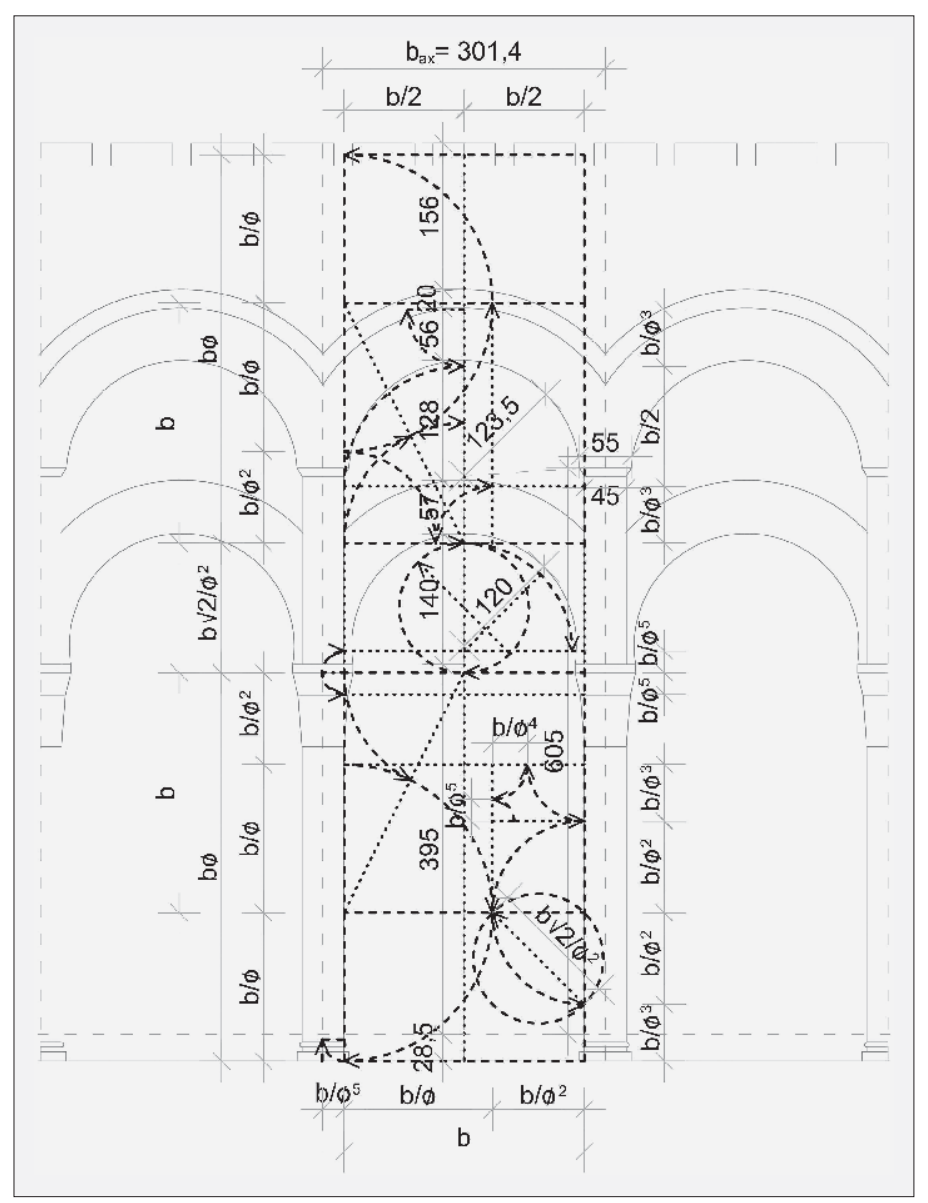

ences between the graphic reconstruction and declared dimensions appear (Figs. 6-9), these are declared at the respective dimension line, firstly by its graphic size, and secondly by its positive or negative deviation from the declared dimensions. The declared dimensions were applied in the arithmetic calculations of algebraic equations. Building elements with unpublished dimensions were reconstructed approximately, based on the published template, but I neither declared their sizes nor applied them in the arithmetic calculations of algebraic expressions of geometric harmonization analyses. Since minor deviations appear among the declared dimensions of the sides of the square, which was undoubtedly conceived as the starting square, the arithmetic quantities were calculated for those two perpendicular dimensions which produce the smallest difference, that is, the maximum net width in the qibla wall, designated $a_{t}$, and minimum net length, designated $a_{1}$. The presented geometric harmonization is drawn on the variable producing the smallest deviations, that is, $a_{1}=7429 \mathrm{~cm}$. All dimensions, either declared or deduced, are declared at the dimension lines. Their arithmetic values are calculated from algebraic
ANALYSIS 1A (A:1A; FIG. 4)

BUILDING, CONSTRUCTION DATE: GREAT MOSQUE IN CÓRDOBA, 785

CONSTRUCTION PHASE: ORIGINAL FORM

CONTENT: GEOMETRIC HARMONIZATION OF ARCADE NORTHEASTERN ELEVATION

ARCHITECTURAL DRAWING: ARCADE NORTHEASTERN ELEVATION ACCORDING TO FERNÁNDEZ-PUERTAS, 2008: 342 (11) 


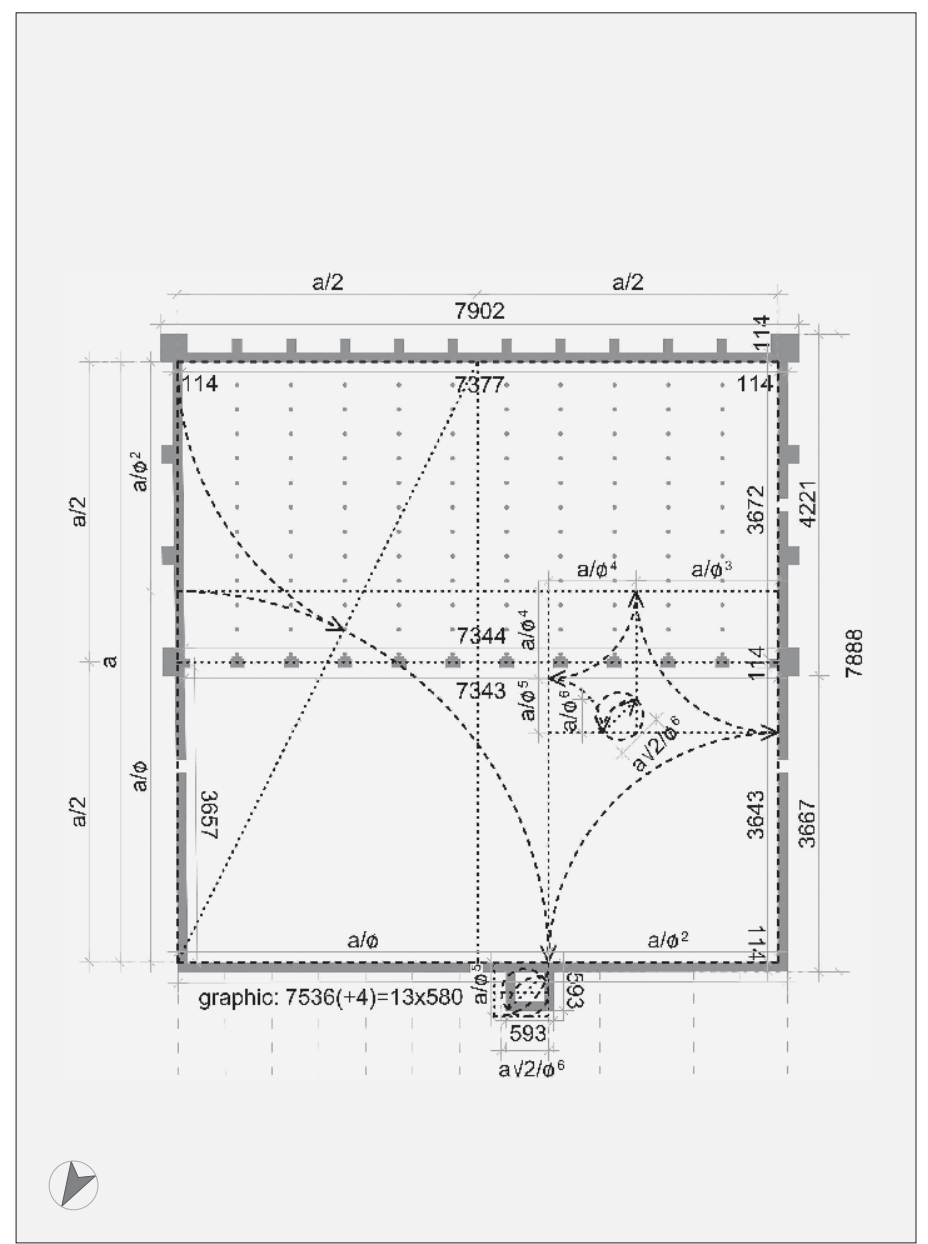

ANALYSIS 1 (A:1; FIG. 5)

BUILDING, CONSTRUCTION DATE: GREAT Mosque IN CóRdoba, 785

CONSTRUCTION PHASE: ORIGINAL FORM

CONTENT: GEOMETRIC HARMONIZATION OF LAYOUT

ARCHITECTURAL DRAWING: LAYOUT, ACCORding to FERnÁNDEZ-PuERTAS, 2000: 220 (2)

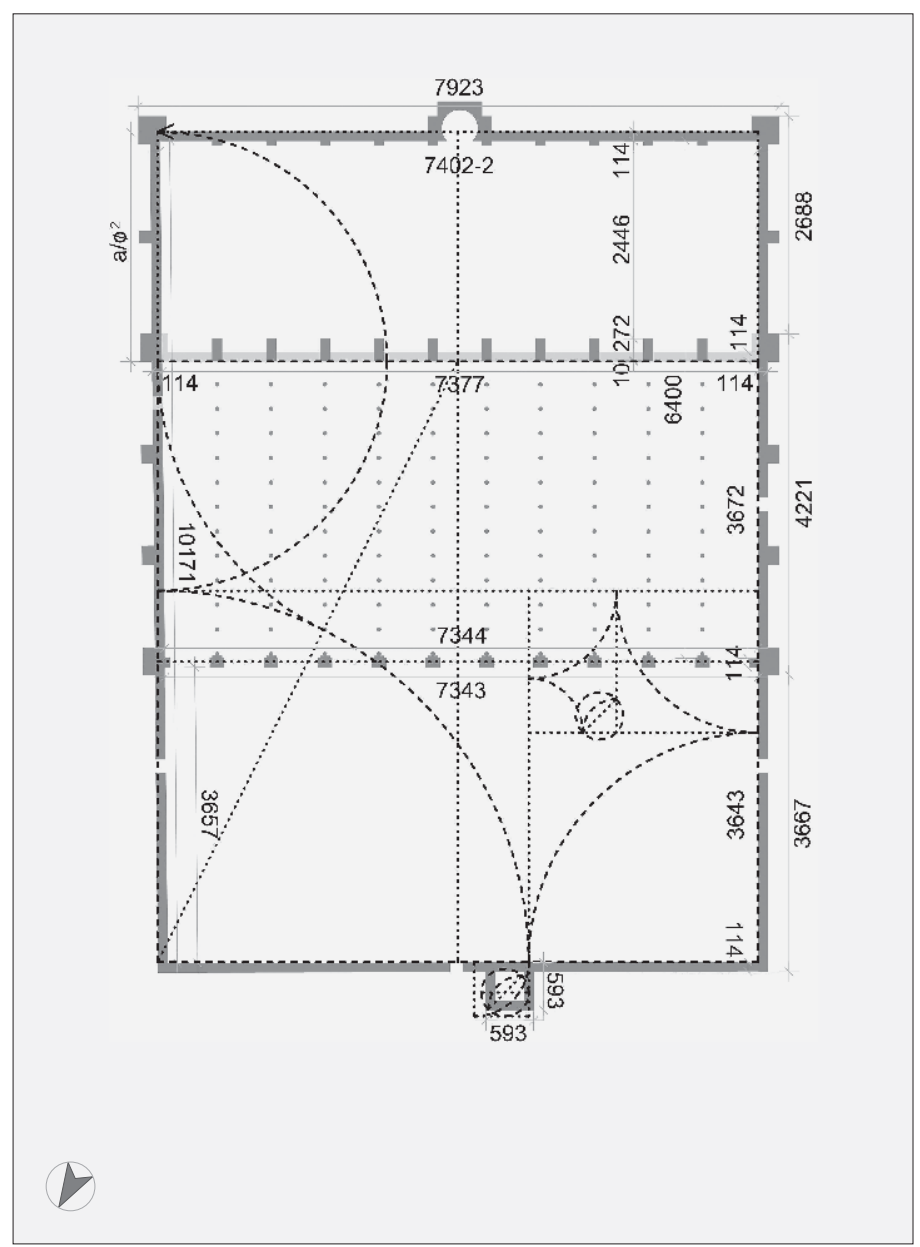

ANALYSIS 2 (A:2; FIG. 6)

BUILDING, CONSTRUCTION DATE: GREAT MOSQUe IN CóRdoba, 848 CONSTRUCTION PHASE: FIRST EXTENSION

CONTENT: GEOMETRIC HARMONIZATION OF LAYOUT

ARCHITECTURAL DRAWING: LAYOUT, ACCORDING TO FERNÁNDEZ-PUERTAS, 2000: 227 (5) expressions of geometric harmonization via introduction of the starting length as variable, designated a, and listed as theoretical values coupled with calculated deviations from real dimensions (Table I). Deviations are expressed in percentages. Deviations less than $1 \%$ are interpreted as negligible, those up to $5 \%$ as small, up to $10 \%$ as significant and over $10 \%$ as large. If calculated alternatively, smaller deviations are taken as the conclusive result for the respective building element.

Fernández-Puertas successfully demonstrated the harmonization of the original form, constructed during the reign of Emir Abd alRahmān I (756-788), and the four extensions based on diagonals of the square and rectangles in 1: $\sqrt{2}$ and $1: \sqrt{ } 3$ ratios (Fig. 2) [Fernández-Puertas, 2000: 220 (2), 227 (5), 232 (7), 236 (10), 242 (14)]. However, the layout posi- tion and size of the original minaret point to the additional principle of harmonization. Namely, the southern façade of the minaret intersects the starting net square width at the point of its division into $a / \Phi$ and $a / \Phi^{2}$ segments (Fig. 5), a fact otherwise neglected by Fernández-Puertas in his own work in the form of its arithmetic variance. The gross square side of the minaret equals $a \sqrt{ } 2 / \Phi^{6}$, a quantity produced by the diagonal of the square with sides $a / \Phi^{6}$ (Fig. 5).

Besides Fernández-Puertas' harmonization based on the axle arch span with the square, equilateral triangle and $\sqrt{ }_{3}$ rectangle applied (Fig. 3) [Fernández-Puertas, 2008: 342 (11), $343(12,13), 344(14)]$, the original arcade elevation can be analyzed alternatively by using the net arch span as starting length b (Fig. 4). The height of the lower arch spring is then bФ. The net height of the lower arch equals 
$\mathrm{b} v_{2} / \Phi^{2}$ and its radius is $b v_{2} / \Phi^{2}-b / \Phi^{5}$. The column width is $2 b / \Phi^{5}$ and column height with capital is $b / \Phi-b / \Phi^{5}$. The thickness of the lower arch is $b / \Phi^{3}$. The radius of the upper arch is $b / 2$ with its center at the vertex of the lower arch. The vertex height of the upper arch, decorative frieze included, is $b \Phi+b v_{2} / \Phi^{2}+b$. The total net room height is $2 b \Phi+b \sqrt{ } 2 / \Phi^{2}$.

The starting length for geometric analyses of all four extensions is the side of the layout grid square of the original building, according to analysis A:1 (Fig. 5).

Fernández-Puertas demonstrated the first extension, constructed during the reign of Emir Abd al-Rahmān II (833-52), as an increase in the original length to measure $\mathrm{a}_{\mathrm{F}} \mathrm{V}_{2}$ (Fig. 2ii). However, it can be alternatively interpreted as an increase in the length to measure $\mathrm{a}+\mathrm{a}$ / $\Phi^{2}$ (Fig. 6).

Fernández-Puertas demonstrated the second extension, constructed during the reign of Caliph Abd al-Rahmān III (912-61), as an increase of the extant length from $a_{F} v_{2}$ to $a_{F} v_{3}$ to new outer wall (Fig. 2iii). Since this extension included the construction of a new minaret as the most accentuated element of its composition, the geometric harmonization of the second extension can be alternatively demonstrated as an increase in the extant length from $a+a / \Phi^{2}$ to $a \Phi$ to the inner façade of the new minaret as located on the inside of the new outer wall (Fig. 7). The northern façade of the new minarets oriented to the main central axis is defined by the expression $a / \Phi-a / \Phi^{5}$, that is, $a / \Phi^{2}+a / \Phi^{5}$. The side of the new minaret layout square is $2 a / \Phi^{6}$, so that the total length of the building is $a \Phi+2 a / \Phi^{6}$. The extant length of the mosque yard of $a / 2$ is increased by the addition of $a / \Phi^{3}$ to the inner façade of the new minaret, so that the total length of the yard up to the new outer wall is $a / 2+a / \Phi^{3}+2 a / \Phi^{6}$.

Fernández-Puertas demonstrated the third extension, constructed during reign of Caliph Al-Hakam II (961-76), at starting length $b_{F}$ equal to the extension's length (Fig. 2iv), so that he actually attributed a value of $b_{F} V_{3}$ to the width of the extant building. The hypotenuse of rectangular triangle so constructed with shorter sides $b_{F}$ and $b_{F} v_{3}$, cartabón in Spanish ${ }^{5}$, is $b_{F} V_{4}$, or $2 b_{F}$. However, geometric harmonization of the third extension can be alternatively demonstrated by adding a value of $a / \Phi$, defined by original construction to

5 Fernández-Puertas shows how a diagonal cuts a square into two rectangular triangles called escuadra with a hypotenuse equal to $\sqrt{2}$, shorter sides equal to 1 and angles of $45^{\circ}$ and $45^{\circ}$, while the diagonal of a rectangle in a $1: \sqrt{ } 3$ ratio cuts it into two rectangular triangles called cartabón with a hypotenuse equal to $V_{4}=2$, shorter sides equal to 1 and $\sqrt{3}_{3}$, angles of $30^{\circ}$ and $60^{\circ}$ [Fernández-Puertas, 2000: 218 (1), 219].

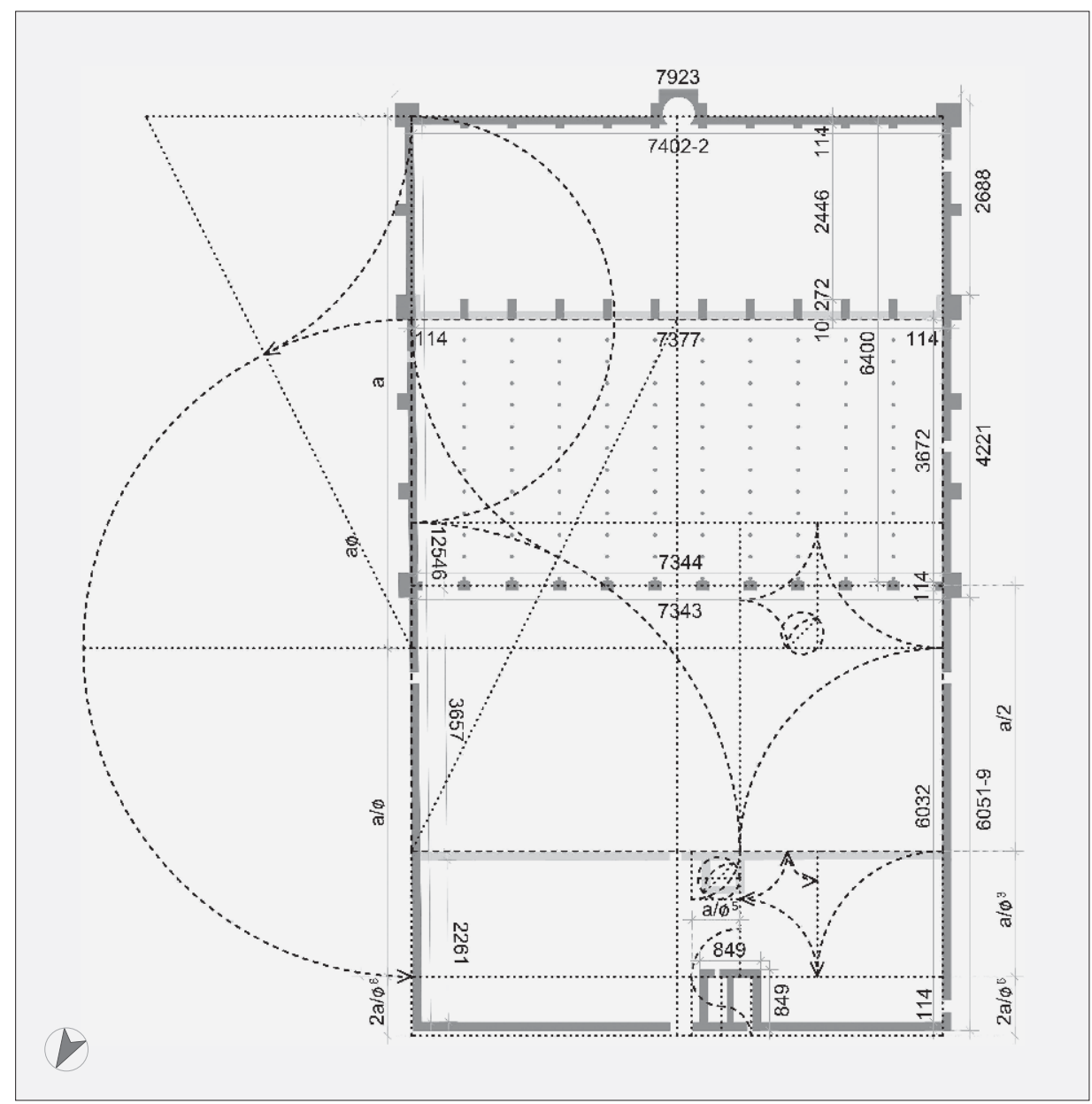

the extant length of the building to the minaret, resulting in the expression $a \Phi+a / \Phi$, which is equal to $\mathrm{a}_{5}$ (Fig. 8). The net length of the third extension is $a / 2$. The gross length of the mihrab room with inner pilasters is $\mathrm{a} \sqrt{2} / \Phi^{5}$.

Fernández-Puertas demonstrated the fourth extension, constructed during the reign of Caliph Hishām II (976-1013), with starting length $\mathrm{C}_{\mathrm{F}}$ equal to the extension's width (Fig. $2 \mathrm{~V}$ ), so that he actually attributed a value of $2 \mathrm{C}_{\mathrm{F}} \mathrm{V}_{3}$ to the length of the extant building. However, geometric harmonization of the fourth extension can be alternatively demonstrated as an extension of the width of the extant mosque yard to a size double that of its extant length (Fig. 9), i.e., $2\left(a / 2+a / \Phi^{3}+2 a / \Phi^{6}\right)$.

Results of geometric analyses - The layout position of the original minaret defined by the first term of the $a / \Phi^{n}$ geometric sequence is a further example of the practice of placing the minaret outside of the starting square and demonstrates the impossibility of harmonization based exclusively on the $\mathrm{a} \vee \mathrm{n}$ geometric sequence. Geometric sequence $a v_{2} / \Phi^{n}$,
ANALYSIS 3 (A:3; FIG. 7)

BUILDING, CONSTRUCTION DATE: GREAT MOSQUE IN CÓRDOBA, 951/2-8

CONSTRUCTION PHASE: SECOND EXTENSION CONTENT: GEOMETRIC HARMONIZATION OF LAYOUT ARCHITECTURAL DRAWING: LAYOUT, ACCORDING TO FERNÁNDEZ-PuERTAS, 2000: 232 (7) 


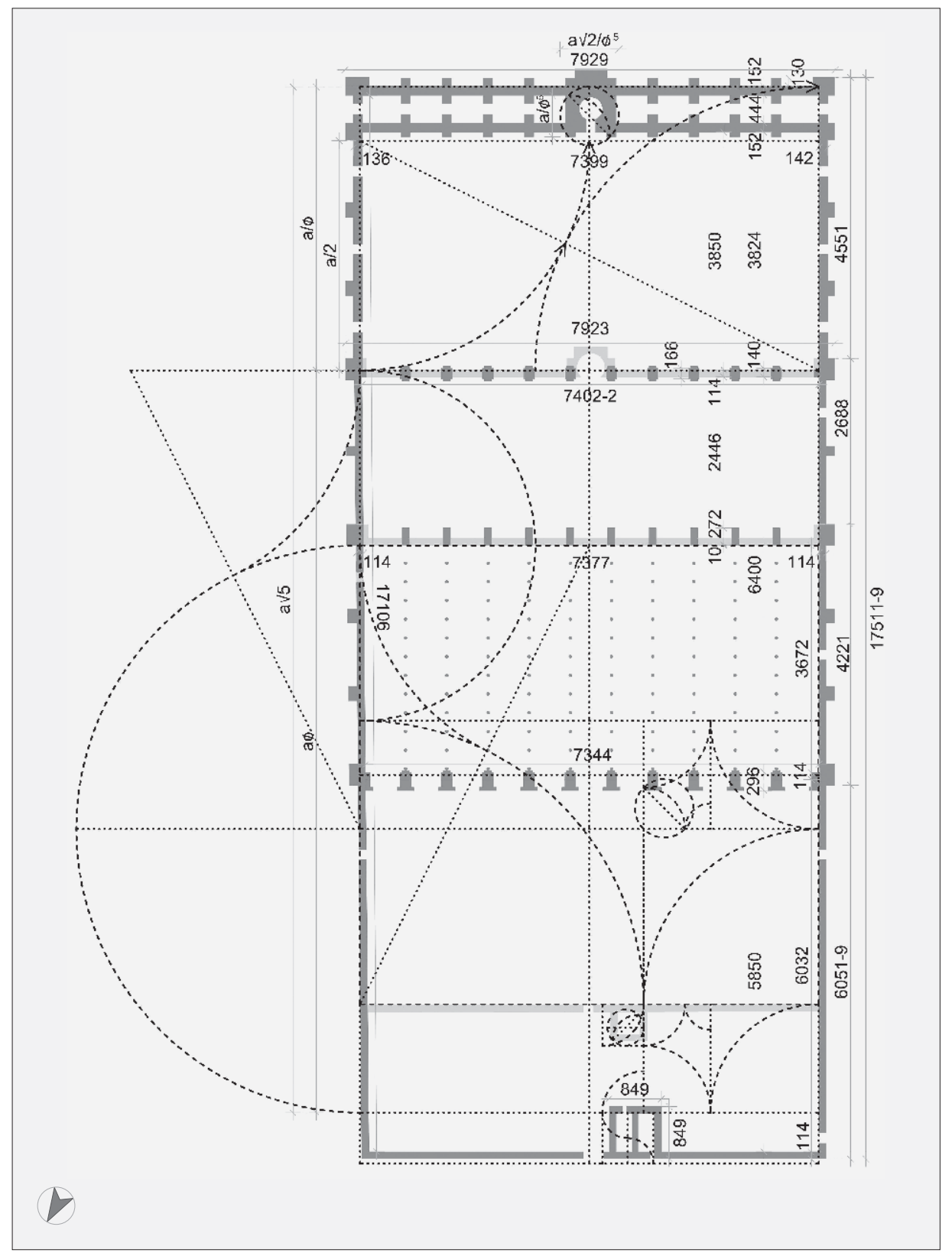

ANALYSIS 4 (A:4; FIG. 8)

BUILDING, CONSTRUCTION DATE: GREAT MOSQUE IN CÓRDOBA, 962

CONSTRUCTION PHASE: THIRD EXTENSION

CONTENT: GEOMETRIC HARMONIZATION OF LAYOUT ARCHITECTURAL DRAWING: LAYOUT, ACCORDING TO FERNÁNDEZ-PUERTAS, 2000: 236 (10) supplemental to the golden section, is applied in the definition of the original minaret layout square size and the height of the lower arch of the original arcade elevation.

The extension series, interpreted by Fernández-Puertas as harmonized by rectangles in $1: \sqrt{ } 2$ and $1: \sqrt{ } 3$ ratios with different starting lengths, are demonstrated here as based on the $a / \Phi^{n}$ geometric sequence with only one starting length, namely, the side of the net square layout of the original building $(A: 1)$. The key extension is the second one $(A: 3)$, where the new layout assumed the form of a golden rectangle with a shorter side equal to the starting length, and the longer side, equal to $\mathrm{a} \Phi$, defined by the inner façade of the new minaret while its outer façade defined the new outer wall. The third extension produced a harmonization value of $a \sqrt{5}$ by adding $a$ length of $a / \Phi$ to extant length a $\Phi$ (A:4). Harmonization of the original arcade elevation is demonstrated by the golden section with the net arch span as the starting length (A:1a).

Results of arithmetic calculation of algebraic expressions of geometric harmonization - Geometric harmonization is demonstrated with four negligible and three minor deviations. The negligible deviations appear in the primary compositional elements of all extensions. The minor deviations appear in the detailed compositional elements, such as the layout size of the minarets and net length of the third extension. One negligible, six minor and one significant deviation have been confirmed in the original arcade elevation analysis.

An increase in deviation values appears in the more detailed aspects of the composition. This can be interpreted as an expected increase due to the adjustments in construction dictated by technical conditions, including the standard building measurements. The share of negligible and minor deviations in the results of detailed analyses is surprisingly high. However, the mere fact that differences appear among the measured dimensions that are undoubtedly conceived as the same, i.e., the sides of starting square, proves that deviations from the measured dimensions which appear in the theoretical values of algebraic expressions of geometric harmonization cannot stand as conclusive proof of demonstrated geometric harmonization.

\section{CONCLUSION}

Unlike Fernández-Puertas' proportion studies of the Great Mosque in Córdoba based on the $a \sqrt{ } n$ geometric sequence, this study has demonstrated an alternative geometric harmonization based on the golden section (a/ $\Phi^{n}$ sequence), supplemented by the $a \sqrt{ } 2 / \Phi^{n}$ sequence. Also, unlike the aforementioned proportion studies, all elements of this alternative geometric harmonization are products of only one starting length applied in the layouts of all construction phases.

The clear advantage of this alternative method is the inclusion of otherwise excluded basic composition elements, i.e., minarets, into a single harmonization pattern for the entire monument and all of its construction phases. This alternative method revealed otherwise hidden proportional qualities, in particular the definition of third extension layout rectangle $a: a v_{5}$ produced by the ini- 
tial square coupled by two smaller golden rectangles $(A: 4)$, i.e., a: $(a \Phi+a / \Phi)$, and the definition of mosque's net height in the original arcade (A:1a) produced by the arch span's net height coupled by one golden rectangle beneath and another above, i.e., $b:\left(2 b \Phi+b \sqrt{ } 2 / \Phi^{2}\right)$.

Moreover, this alternative approach points to the possibility of a composition based on the combination of two different geometric sequences, namely, aVn, as applied by Fernández-Puertas, and $a / \Phi^{n}$, as applied by this alternative method. It may well be that the very layout position and size of the second extension's new minaret producing golden rectangle a:a $\Phi$, by its inner façade (A:3, Fig. 5) and rectangle $a: a V_{3}$, by the mosque's outer wall (Fig. 2iii), were designed to combine the two sequences in one composition as an objective of harmonization.

The proximity of deviations in the whole composition thus constitutes a possibility for research and findings of alternative patterns of geometric harmonization applied to Islamic architectural monuments studied in the literature by other methods and geometric sequences.

Applying the same geometry of harmonization with one and the same starting length in the original structure and all extensions proves respect for the original form by the extension designs not only in terms of space and structure, but also in geometric harmonization. This opens the additional possibility of proof stabilization in the design of architectural structures when reconstructing monuments that underwent multiple subsequent expansions and those that are preserved in their original form.

[Translated by Edward Bosnar, Apostrof d.o.o., Zagreb]

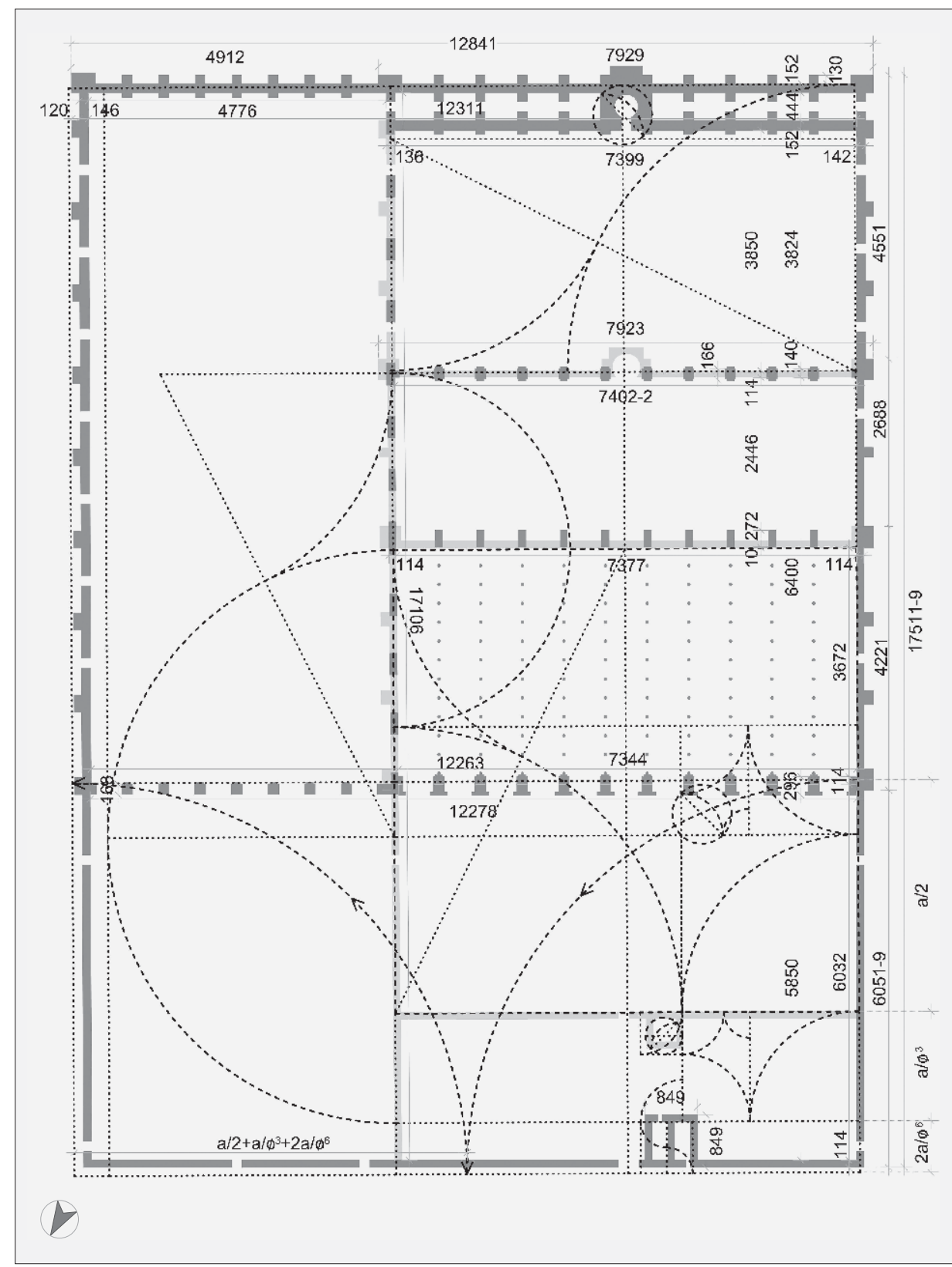

ANALYSIS 5 (A:5; FIG. 9)

BUILDING, CONSTRUCTION DATE: GREAT Mosque IN CóRdoba, 988 CONSTRUCTION PHASE: FOURTH EXTENSION

CONTENT: GEOMETRIC HARMONIZATION OF LAYOUT

ARCHITECTURAL DRAWING: LAYOUT, ACCORDING TO FERNÁNDEZ-PUERTAS, 2000: 242 (14) 
TABLE I LIST OF ALGEBRAIC EXPRESSIONS, ARITHMETIC RESULTS, DIMENSIONS AND DEVIATIONS

\begin{tabular}{|c|c|c|c|c|}
\hline element & algebraic & \begin{tabular}{|l} 
arithmetic \\
$(\mathrm{cm})$
\end{tabular} & \begin{tabular}{|l} 
dimension \\
$(\mathrm{cm})$
\end{tabular} & deviation \\
\hline $\begin{array}{l}\text { net width or length } \\
\text { of the original building }\end{array}$ & $a$ & - & $\begin{array}{l}a_{t}=7377 \\
a_{1}=3643+114+3672=7429\end{array}$ & $-0.700 \%$ \\
\hline $\begin{array}{l}\text { distance between southern } \\
\text { façade of original minaret } \\
\text { and northern façade } \\
\text { of original building }\end{array}$ & $\mathrm{a} / \Phi$ & - & unknown & - \\
\hline $\begin{array}{l}\text { side of layout square } \\
\text { of original minaret }\end{array}$ & $\mathrm{a} \sqrt{ } 2 / \Phi^{6}$ & $\begin{array}{l}581.47\left(\mathrm{a}_{\mathrm{t}}\right) \\
585.56\left(\mathrm{a}_{1}\right)\end{array}$ & 593 & $\begin{array}{l}-1.944 \% \\
-1.255 \%\end{array}$ \\
\hline $\begin{array}{l}\text { length of } 1^{\text {st }} \text { extension } \\
\text { (including new qibla wall) }\end{array}$ & $\mathrm{a} / \Phi^{2}$ & $\begin{array}{l}2817.80\left(a_{1}\right) \\
2837.66\left(a_{1}\right)\end{array}$ & $2446+272+10+114=2842$ & $\begin{array}{l}-0.852 \% \\
-0.153 \%\end{array}$ \\
\hline $\begin{array}{l}\text { building length after } \\
2^{\text {nd }} \text { extension (including } \\
\text { new qibla wall) to inner } \\
\text { façade of new minaret }\end{array}$ & $\mathrm{a} \Phi$ & $\begin{array}{l}11935.99\left(\mathrm{a}_{1}\right) \\
12020.12\left(\mathrm{a}_{1}\right)\end{array}$ & $\begin{array}{l}114+6032+114+3672+ \\
+2842-849=11925\end{array}$ & $\begin{array}{l}+0.092 \% \\
+0.798 \%\end{array}$ \\
\hline $\begin{array}{l}\text { side of new minaret's layout } \\
\text { square }\end{array}$ & $2 \mathrm{a} / \Phi^{6}$ & $\begin{array}{l}822.32\left(\mathrm{a}_{\mathrm{t}}\right) \\
828.11\left(\mathrm{a}_{1}\right)\end{array}$ & 849 & $\begin{array}{l}-3.143 \% \\
-2.461 \%\end{array}$ \\
\hline gross length of $3^{\text {rd }}$ extension & $\mathrm{a} / \Phi$ & $\begin{array}{l}4559.33\left(\mathrm{a}_{\mathrm{t}}\right) \\
4591.47\left(\mathrm{a}_{1}\right)\end{array}$ & $3850+152+444+152=4598$ & $\begin{array}{l}-0.841 \% \\
-0.142 \%\end{array}$ \\
\hline net length of $3^{\text {rd }}$ extension & $a / 2$ & $\begin{array}{l}3688.5\left(a_{t}\right) \\
3714.5\left(a_{1}\right)\end{array}$ & 3850 & $\begin{array}{l}-4.195 \% \\
-3.519 \%\end{array}$ \\
\hline $\begin{array}{l}\text { building (yard) width by } \\
4^{\text {th }} \text { extension (gross) }\end{array}$ & $2\left(\mathrm{a} / 2+\mathrm{a} / \Phi^{3}+2 \mathrm{a} / \Phi^{6}\right)$ & $\begin{array}{l}12504.64\left(a_{t}\right) \\
12592.78\left(a_{1}\right)\end{array}$ & $12278+2 \times 114=12506$ & $\begin{array}{l}-0.011 \% \\
+0.694 \%\end{array}$ \\
\hline $\begin{array}{l}\text { net arch span of original } \\
\text { arcade }\end{array}$ & $\mathrm{b}$ & - & $256.41^{\star}$ & \\
\hline height of lower arch spring & $\mathrm{b} \Phi$ & 414.87 & $395+28,5=423,5$ & $-2.038 \%$ \\
\hline net height of lower arch & $\mathrm{b} V 2 / \Phi^{2}$ & 138.51 & 140 & $-1.064 \%$ \\
\hline radius of lower arch & $\mathrm{b} V 2 / \Phi^{2}-\mathrm{b} / \Phi^{5}$ & 115.39 & 120 & $-3.842 \%$ \\
\hline column width & $2 \mathrm{~b} / \Phi^{5}$ & 46.25 & 45 & $+2.778 \%$ \\
\hline thickness of lower arch & $\mathrm{b} / \Phi^{3}$ & 60.53 & 57 & $+6.193 \%$ \\
\hline $\begin{array}{l}\text { radius and net height of } \\
\text { upper arch }\end{array}$ & $\mathrm{b} / 2$ & 128.205 & $\begin{array}{l}123.5 \text { (radius) } \\
128 \text { (height) }\end{array}$ & $\begin{array}{l}+3.810 \% \\
+0.160 \%\end{array}$ \\
\hline $\begin{array}{l}\text { height of upper arch vertex } \\
\text { with decorative frieze }\end{array}$ & $\mathrm{b} \Phi+\mathrm{b} V_{2} / \Phi^{2}+\mathrm{b}$ & 809.79 & $28,5+395+140+57+128+56+20=824,5$ & $-1.784 \%$ \\
\hline net height of the room & $2 \mathrm{~b} \Phi+\mathrm{b} V_{2} / \Phi^{2}$ & 968.25 & $28,5+395+140+57+128+56+20+156=980,5$ & $-1.249 \%$ \\
\hline
\end{tabular}

*starting length $b$ calculation:

$b_{a x}=W_{1}+2 V\left[r^{2}-\left(h_{1}-h_{2}-h_{3}-h_{4}+r\right)^{2}\right]=55+2 V\left[123,5^{2}-(605-395-140-57-128+123,5)^{2}\right]=301,41$

$b=b_{a x}-w_{2}=301,41-45=256,41$

signing explanation:

axle span $\left(b_{a x}\right)$; capital width $\left(w_{1}\right)$; column width $\left(w_{2}\right)$; net radius of upper arch $(r)$; height of upper capital $\left(h_{2}\right)$;

height of lower capital $\left(h_{2}\right)$; gross height of lower arch $\left(h_{3}\right)$; net height of upper arch $\left(h_{4}\right)$

\section{BIBLIOGRAPHY}

1. ARnold, F. (2017) Islamic Palace Architecture in the Western Mediterranean. $1^{\text {st }}$ ed. Oxford: Oxford University Press. https://doi.org/10.1093/ acprof:oso/9780190624552.001.0001

2. Azızova, B.M. (2015) 'Architectural Harmonization \& Proportioning of Juma Mosque in Khiva City, Uzbekistan', Young Scientists USA, 3[online]. Available at: http://www.youngscientistsusa.com/archive/3/287 [Accessed: 30 December 2015].

3. Balasubramaniam, R. (2009) 'New insights on the modular planning of the Taj Mahal', Current Science, 97 (1), pp. 42-49.

4. Begley, W.E. and DesAi, Z.A. (1989) Taj Mahal, The Illumined Tomb: An Anthology of Seventeenth-Century Mughal and European Documentary Sources. $1^{\text {st }}$ ed. Cambridge, MA: The Aga Khan Program for Islamic Architecture, Harvard University and Massachusetts Institute of Technology.

5. Bentley Ševčenko, M. (ed.) (1988) Theories and Principles of Design in the Architecture of Islamic Societies. $1^{\text {st }}$ ed. Cambridge, MA: The Aga Khan Program for Islamic Architecture at Harvard University and MIT.

6. BIER, C. (2012) 'The Decagonal Tomb Tower at Maragha and Its Architectural Context: Lines of Mathematical Thought', Nexus Network Journal, 14 (2), pp. 251-273. https://doi.org/10.1007/ S00004-012-0108-6

7. BLASI, C. (1997) Restoration of Ottoman Domes and Bridges in Mostar. In: Studies in Ancient Structures: Proceedings of the International Conference, July 14-18, 1997, Istanbul, Turkey. İstanbul: Yıldız Technical University, Faculty of Architecture Publication, pp. 605-613.

8. Boussora, K. and Mazouz, S. (2004) 'The Use of the Golden Section in the Great Mosque at Kairouan', Nexus Network Journal, 6 (1), pp. 7-16. https://doi.org/10.1007/s00004-004-0002-y

9. Bulatov, M.S. (1988) Geometričskaja garmonizacija $v$ arhitekture Srednej Azii 9-15 vv. D Istoriko-teoreticeskoe issledovanie. $2^{\text {nd }}$ ed. Moscow: Izdatel'stvo „Nauka“, Glavnaja redakcija vostočnoj literatury.

10. BURCKHARDT, T. (2009) Art of Islam: Language and Meaning. $2^{\text {nd }}$ ed. Bloomington: World Wisdom.

11. Chorbachi, W. and Loeb, A.L. (1992) 'An Islamic Pentagonal Seal, From Scientific Manuscripsts of the Geometry of Design' in Hargittai, I. (ed.) Fivefold Symmetry. $1^{\text {st }}$ ed. Singapore: World Scientific Publishing Co. Ptc. Ltd., pp. 283-305. https://doi.org/10.1142/9789814439497_0018

12. CReswell, K.A.C. $(1932,1940)$ Early Muslim Architecture, I-II. $1^{\text {st }}$ ed. Oxford: University Press.

13. Creswell, K.A.C. (n.d., $1^{\text {st }}$ ed. 1958) A Short Account of Early Muslim Architecture. $2^{\text {nd }}$ ed. Harmondsworth. Middlesex: Penguin Books.

14. Critchlow, K. (2011) Islamic Patterns: An Analytical and Cosmological Approach. $3^{\text {rd }}$ ed. London: Thames \& Hudson.

15. DabBour, L. (2012) 'Geometric proportions: The underlying structure of design process for Islamic geometric patterns', Frontiers of Architec- 
tural Research, 1, pp. 380-391, https://doi.org /10.1016/j.foar.2012.08.005.

16. El-Said, I. and Parman, A. (1976) Geometric Concepts in Islamic Art. $1^{\text {st }}$ ed. London: World of Islam Festival Publishing Company.

17. El-SAID, I. (1993) Islamic Art and Architecture: The Systems of Geometric Design. $1^{\text {st }}$ ed. Reading: Garnet Publishing Ltd.

18. Ettinghausen, R., Grabar, O. and Jenkins-MaDINA, M. (2001) Islamic Art and Architecture 650-1250. $1^{\text {st }}$ ed. New Haven and London: Yale University Press and Pelican History of Art.

19. Ewert, CH. (1986) The Mosque of Tinmal (Morocco) and Some New Aspects of Islamic Architectural Typology. In: Mortimer Wheeler Archeological Lecture, Proceedings of the British Academy, Ixxii1986. London: British Academy, pp. 115-148.

20. Fernández-Puertas, A. (1994) 'Spain and North Africa', in: Frishman, M. and Khan, H. U. (eds.) The Mosque. $1^{\text {st }}$ ed. London: Thames and Hudson, pp. 101-117.

21. Fernández-Puertas, A. (2000), ‘l. Mezquita de Córdoba. Trazado proporcional de su planta general (siglos VIII-X)', Archivo Español de Arte, LXXIII (291), pp. 217-291. https://doi.org/10.39 89/aearte.2000.v73.i291.829

22. Fernández-Puertas, A. (2008) 'Il.Mezquita de Córdoba. 'Abd al-Rahmān I (169/785-786). El trazado proporcional de la planta y alzado de las arquerías del oratorio. La qibla y el mihrāb del siglio VIII', Archivo Español de Arte, LXXXI (324), pp. 333-356, https://doi.org/10.3989/ aearte.2008.v81.i324.127

23. Fleurent, G.M. (1992) 'Pentagon and Decagon Designs in Islamic Art' in: Hargittai, I. (ed.) Fivefold Symmetry. $1^{\text {st }}$ ed. Singapore: World Scientific Publishing Co. Ptc. Ltd., pp. 263-281. https: //doi.org/10.1142/9789814439497_0017

24. Frishman, M. and Khan, H.U. (eds.) (1994) The Mosque. $1^{\text {st }}$ ed. London: Thames and Hudson.

25. Hejazi, M. (2005) 'Geometry in nature and Persian architecture', Building and Environment, 40 (10), pp. 1413-1427. https://doi.org/10.1016 /j.buildenv.2004.11.007

26. Hillenbrand, R. (1994) Islamic Architecture. $1^{\text {st }}$ ed. New York: Columbia University Press.

27. Kuingelhofer, W. G. (1988) 'The Jahangiri Mahal of the Agra Fort: Expression and Experience in Early Mughal Architecture', Muqarnas, 5, pp. 153-169. https://doi.org/10.2307/1523115

28. LORZĀDEH, H. (1995/6) Âhyā-yi hunarhā-yi āzy$\bar{a} d r a f t e h, 1^{\text {st }}$ ed. Tehran: Mawlā.

29. Lu, P.J. and Steinhardt, P.J. (2007) 'Decagonal and Quasi-Crystalline Tilings in Medieval Islamic Architecture', Science, 315 (5815) [online], pp. 1106-1110. Available at: https://doi.org/10.1126/ science.1135491 [Accessed: 10 Novemeber 2021].

30. MAкоVICKY, E. (1992) '800-Year-Old Pentagonal Tiling from Marāgha, Iran, and the New Varieties of Aperiodic Tiling It Inspired' in Hargittai, I. (ed.) Fivefold Symmetry. $1^{\text {st }}$ ed. Singapore: World Scientific Publishing Co. Ptc. Ltd., pp. 67-86. https: //doi.org/10.1142/9789814439497_0004

31. MarCH, L. (1998) Architectonics of Humanism: Essays on Number in Architecture. $1^{\text {st }}$ ed. Chichester: Academy Editions.

32. MiCHELL, G. (ed.) (1991) Architecture of the Islamic World. $2^{\text {nd }}$ ed. London: Thames and Hudson.
33. MIR, M.N. (1996) 'Shalamar Garden, Lahore: The Other Side of the Square' in: Hussain, M. et al. (eds.) The Mughal Garden. $1^{\text {st }}$ ed. Lahore: Ferozsons (Pvt.) Ltd., pp. 173-179.

34. NecıpoĞLu, G. (1995) TheTopkapi Scroll: Geometry and Ornament in Islamic Architecture. $1^{\text {st }}$ ed. Santa Monica: The Getty Center for the History of Art and the Humanities.

35. Özdural, A. (1995) 'Omar Khayyam, Mathematicians, and Conversazioni with Artisans', Journal of the Society of Architectural Historians, 54 (1), pp. 54-71. https://doi.org/10.2307/991025

36. Özdural, A. (2000) 'Mathematics and Arts: Connections between Theory and Practice in the Medieval Islamic World', Historia Mathematica, 27 (2), pp. 171-201. https://doi.org/ 10.1006/hmat.1999.2274

37. Özdural, A. (2015) 'The Use of Cubic Equations in Islamic Art and Architecture' in: Williams, K. and Ostwald, M.J. (eds.) Architecture and Mathematics from Antiquity to the Future, Volume I: Antiquity to the $1500 \mathrm{~s}$. $1^{\text {st }}$ ed. Switzerland: Springer International Publishing. pp. 467-481. https://doi.org/10.1007/978-3-319-00137-1_32

38. Padovan, R. (1999) Proportion: Science, Philosophy, Architecture. $1^{\text {st }}$ ed. London: Taylor \& Francis Routledge. https://doi.org/10.4324/97 80203477465

39. Pejaković, M. (2000) Zlatni rez. $1^{\text {st }}$ ed. Zagreb: Art studio Azinović d.o.o.

40. Pour Ahmadi, M. (2012) 'A Geometrical Analysis of the Mausoleum of Sheikh Zāhed-e Gīlāni', Nexus Network Journal, 14 (2), pp. 391-406. https://doi.org/10.1007/s00004-012-0114-8

41. PūrnĀDARĪ, Ḥ. (2000/1) Sha'rbaf wa āthārash: Garah wa kärbandī. $1^{\text {st }}$ ed. Tehran: Sāzamān mīrāt farhangī kashwar.

42. SAĞDiç, Z. (2015) 'Ottoman Architecture: Relationships between Architectural Design and Mathematics in Sinan's Works' in Williams, K. and Ostwald, M.J. (eds.) Architecture and Mathematics from Antiquity to the Future, Volume II: The 1500 s to the Future. $1^{\text {st }}$ ed. Switzerland: Springer International Publishing. pp. 95-106. https://doi.org/10.1007/978-3-319-00143-2_6

43. SARHANGI, R. (2012) 'Interlocking Star Polygons in Persian Architecture: The Special Case of the Decagram in Mosaic Designs', Nexus Network Journal, 14 (2), pp. 345-372. https://doi.org/ 10.1007/s00004-012-0117-5

44. TabBaA, Y. (1988) 'Geometry and Memory in the Design of the Madrasat al-Firdows in Allepo' in: Bentley Ševčenko, M. (ed.) Theories and Principles of Design in the Architecture of Islamic Societies. $1^{\text {st }}$ ed. Cambridge, MA: The Aga Khan Program for Islamic Architecture at Harvard University and MIT, pp. 23-34.

45. TAвbAA, Y. (2008) 'Andalusian Roots and Abbasid Homage in the Qubbat al-Barudiyyinin Marrakech', Muqarnas, 25 (1), pp. 133-146. https:// doi.org/10.1163/22118993_02501006

46. TUNCER, O.C. (1986) Anadolu Selçuklu mimarisi ve Moğollar. $1^{\text {st }}$ ed. Ankara: Türkiye vakıflar bankası.

47. YetKın, S.K. (1965) İslâm Mimarisi. $1^{\text {st }}$ ed. Ankara: Ankara Üniversitesi Türk ve İslâm Sanatları Enstitüsü.

\section{AUTHOR'S BIOGRAPHY}

SENAD NANIC, BA architecture (1993), MA philosophy of science (1996), is a Ph.D. candidate at the Faculty of Architecture in Zagreb. He has designed over 100 projects, of which over 60 have been developed, including reconstructions of monuments. He has written approximately 80 papers on the philosophy of science, Islamic architecture theory and social phenomenology. He has published three books and contributed four chapters to edited books.

The author prepared the whole work. 
